\title{
MDM2 SNP309 polymorphism in Turkish population
}

\section{Türk popüllasyonunda MDM2 SNP309 polimorfizmi}

\section{Ayca Taş ${ }^{1}$ İ́smail Sari ${ }^{2}$, Tuğba Ağbektaș ${ }^{3}$, Yavuz Silliğ $\breve{g}^{3}$}

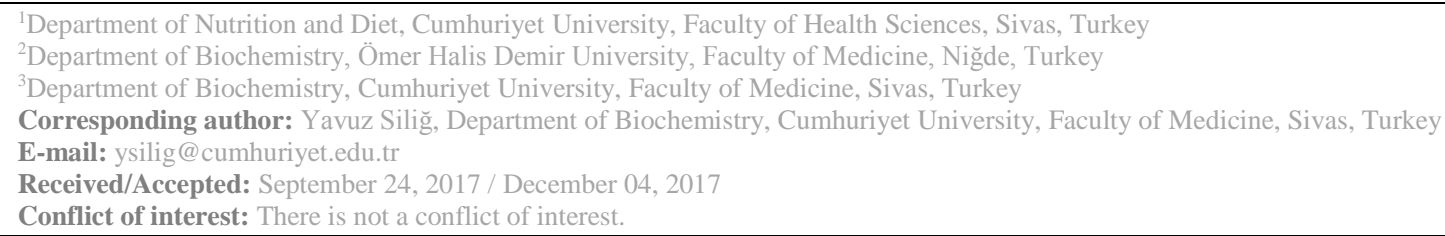

\section{SUMMARY}

Objective: Murine double minute 2 (MDM2) gene has a critical role on regulation of p53 tumor suppressor pathway. MDM2 is a major negative regulator of $\mathrm{p} 53$ function. $M D M 2$ protein regulates $\mathrm{p} 53$ function through multiple independent pathways. The present study aims to determine the frequency of MDM2 gene SNP309 (rs2279744) polymorphism in the Turkish population.

Method: This study included a total of 301 healthy Turkish individuals (159 females (53.0\%) and 141 males (47.0\%) between 2014 and 2016. The frequency of T309G MDM2 rs2279744 polymorphism was identified using restriction fragment length polymorphism-polymerase chain reaction (RFLP-PCR) method.

Results: The mean age of the study population was 49,80 16,4 years $(51,97 \pm 15,98$ years in men and 47,58 $\pm 16,82$ years in women). Genotype frequencies for MDM2 rs2279744 polymorphism were found to be $17.9 \% \mathrm{TT}, 55.2 \% \mathrm{TG}$, and $26.9 \%$ GG.

Conclusions: The present study provides information on the allele and genotype frequency distribution of $M D M 2$ gene rs2279744 polymorphism in the Turkish population, which can be used as a reference parameter for the investigation of susceptibility to various disorders, particularly cancer.

Keywords: Murine double minute 2, MDM2, polymorphism, Turkish Population.

\section{ÖZET}

Amaç: Murine double minute 2 (MDM2) geni p53 tümör süpressör yolağının düzenlenmesinde kritik bir role sahiptir. MDM2, p53 fonksiyonunda büyük bir negatif regülatördür. MDM2 proteini birbirinden bağımsız birçok yolla p53 fonksiyonunu düzenler. Bu çalışmada bir Türk Populasyonunda MDM2 geni SNP309 (rs2279744) polimorfizm sıklığının belirlenmesi amaçlanmıştır.

Yöntem: Bu çalışmada, MDM2 rs2279744 polimorfizm sıklığı toplam 301 (kadın: 159, \% 53,0 ve erkek: 141, \% 47,0) Türk sağlıklı bireyde incelendi. T309G MDM2 rs2279744 polimorfizim sıklığ1 301 sağlıklı kontrolde RFLP-PCR metoduyla belirlendi.

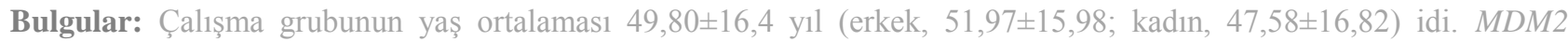
rs2279744 polimorfizmine ait gözlenen genotip frekanslar1 \% 17.9 TT, \% 55.1 TG ve \%26.9 GG olarak tespit edildi. Sonuç: Bu çalışma, Türk toplumunda MDM2 geni rs2279744 polimorfizminin allel ve genotip frekans dağılımları hakkında bilgi vermektedir. Bu allel ve genotip dağılımları kanser başta olmak üzere birçok hastalığa yatkınlığın araştırılmasında referans parametre olacaktır.

Anahtar sözcükler: Murine double minute 2, MDM2, polimorfizm, Türk Popülasyonu 


\section{INTRODUCTION}

Murine double minute 2 (MDM2) gene was firstly obtained from the "double minute" (small chromatin pieces without centromeres) chromosomes of the spontaneously transformed mouse cell lines ${ }^{1}$. Human homologous of MDM2, HDM2 (Human double minute 2), is localized on the $12 q 13-14$ region of the chromosome. MDM2 is a 90 kilodalton $(\mathrm{kD})$ protein which can form a complex with p53 tumor suppressor protein ${ }^{2}$. p53 protein activates the transcription of $M D M 2$ gene $^{3}$. In case of any damage to the DNA, degradation of p53 protein stops or another tumor suppressor, namely $p 14 A R F$, which is stimulated by any kind of increased oncogenic activity binds to MDM2 and contributes to the activation of p53 protein. The product of P14ARF gene binds and inhibits MDM2, thereby, playing a role in the activation of p53. Binding of P14ARF to MDM2 prevents the interactions between MDM2 and p53, as well as stimulating degradation of $\mathrm{MDM} 2{ }^{4}$. MDM2 inhibits the activity of $\mathrm{p} 53$ protein and ensures degradation of this protein by ubiquitin ligase ${ }^{5}$. The level of MDM2 protein within cell or an organism has a major influence on p53 response and formation of several diseases such as cancer ${ }^{6}$. p53 represents the major pathway of interaction between tumor functions and MDM2 proteins form the autoregulatory feedback cycle. In this cycle, p53 positively regulates MDM2 levels, while MDM2 negatively regulates p53 levels and activity. In addition, MDM2 also contributes to carcinogenesis irrespective of $\mathrm{p} 53$ by inhibiting the functions of E2F family transcription factors and $\mathrm{Rb}$ (retinablastoma) and transition of normal cells to $\mathrm{G}_{0} / \mathrm{G}_{1}-\mathrm{S}$ phase ${ }^{7}$. If a mutation occurs in the region of MDM2 that affects the p53 gene, p53 gene can be suppressed without any control and the cell cycle of a cell with DNA damage may not be stopped $^{1}$.

MDM2 SNP309 is a functional polymorphism that effects $p 53$ protein levels in a cell. Replacement of $\mathrm{G}$ allele by $\mathrm{T}$ allele increases the binding affinity of Sp1 transcription activator. Therefore, expression of the MDM2 gene increases. Over-expression of $M D M 2$ prevents $p 53$ functions as well as aiding in the escape of damaged cells from cell cycle checkpoints and becoming carcinogenic ${ }^{8,9}$. In the present study, we aimed to investigate rs 2279744 single nucleotide polymorphism which results in TG replacement in position 309 of MDM2 in 301 healthy individuals and genotype distribution.

\section{MATERIALS AND METHODS}

The study protocol was approved by both scientific and ethics committees and written informed consents were obtained from all participants. In the present study, a total of 301 (females: 142, 47,2 \%) and males: 159, 52,8 \%) Turkish healthy individuals were studied. The mean age of study population was $49,80 \pm 16,4$ year (males, $51,97 \pm 15,98$; females, 47,58 $\pm 16,82$ ). Healthy controls were composed of 301 individuals who visited the outpatient department for physical examination, without tumors. All participants in the study gave informed consent, provided a blood sample, and completed a comprehensive epidemiologic questionnaire. A questionnaire given to each control collected information on demographic factors, such as age and sex.

Two milliliters peripheral blood samples were collected in to sitrat containing tubes from all subjects. DNA was extracted from whole blood by salting out procedure as soon as the samples reached to laboratory ${ }^{10}$.

MDM2 SNP309 polymorphism was analyzed using a PCR-RFLP method. This polymorphic side in MDM2 gene was amplificated on a thermal cycler (Applied Biosystems Gene AmpR PCR system 9700, USA) by using a forward primer (5'-CGC GGG AGT TCA GGG TAA AG-3') and a reverse primer (5'- CTG AGT CAA CCT GCC CAC TG$\left.3^{\prime}\right)$. The reaction performed in $25 \mu \mathrm{L}$ of total volume containing $10 \mathrm{mmol} / \mathrm{L}$ Tris- $\mathrm{HCl}(\mathrm{pH} 8.3$ at $\left.25^{\circ} \mathrm{C}\right), 50 \mathrm{mmol} / \mathrm{L} \mathrm{KCl}, 1.5 \mathrm{mmol} / \mathrm{L} \mathrm{MgCl} 2,2.5 \mathrm{U}$ of Taq DNA polymerase (Fermentas), $5 \mathrm{nmol}$ of each of four deoxynucleotide triphosphates (dNTPs-Fermentas), 10 pmol of each of the appropriate primers and $100 \mathrm{ng}$ of genomic DNA. PCR conditions were one cycle of $95^{\circ} \mathrm{C}$ for $5 \mathrm{~min}$; 30 cycles of $94^{\circ} \mathrm{C}$ for $60 \mathrm{~s}, 55^{\circ} \mathrm{C}$ for $60 \mathrm{~s}, 72^{\circ} \mathrm{C}$ for $60 \mathrm{~s}$, and one cycle of $72^{\circ} \mathrm{C}$ for $5 \mathrm{~min}$. After PCR amplification, a fragment with 157 base pair (bp) was obtained. For RFLP analysis, the PCR products were digested with MspAlI restriction endonuclease (RE) enzyme (Promega) at $37^{\circ} \mathrm{C}$ during overnight, according to the manufacturer's instructions. Both PCR and RFLP products were separated on $2 \%$ agarose gel stained with GelRed $^{\mathrm{TM}}$ Dropper Bottle (Sweden) and imaged on UV transilluminator. Genotypes of the rs2279744 polymorphism were identified according to presence or absence of recognition side of MspAlI RE enzyme. The wild type genotype (TT) has no recognition side of the enzyme. However, a recognition region of the RE enzyme occurs with substitution of T-to-G nucleotide in 309 position of MDM2 gene in polymorphic type genotype (GG). Thus, two fragments (110 and $47 \mathrm{bp}$ ) shown in GG genotype $^{11}$ (Figure 1). 


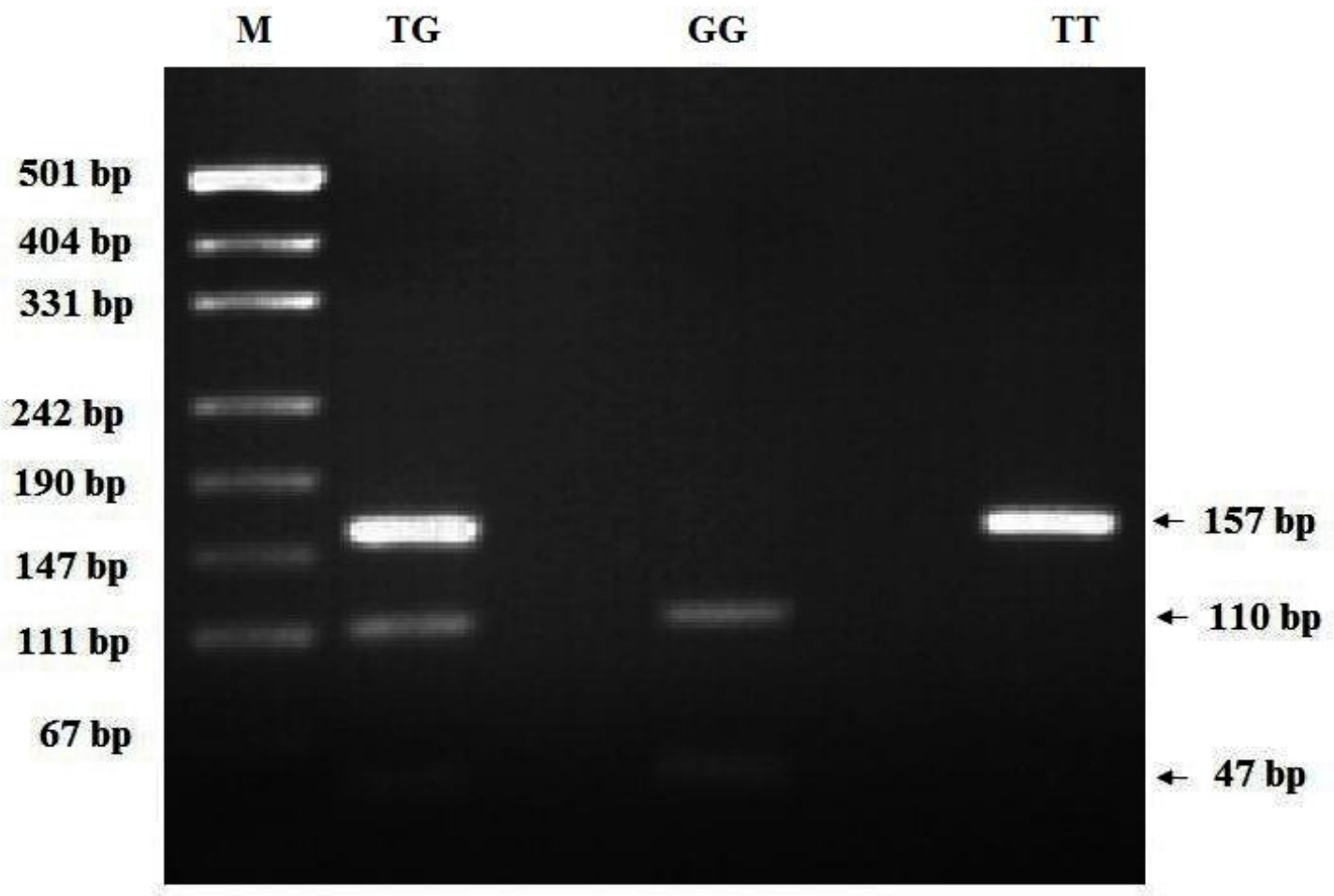

Figure 1. PCR-RFLP patterns of polymorphisms of MDM2 T309G. M: pUCI19/Msp I DNA ladder (501, 489, 404, 331, 242, 190, 147, 111, 110bp); MDM2 PCR product, 157 bp, TG (157, 110, 47 bp); GG (110, $47 \mathrm{bp})$; TT (157 bp $)^{35}$

For all polymorphisms studied, all statistical analyses were performed using the Statistical Package for Social Sciences Program (SPSS, version 15). Genotype-related odds ratios (ORs), their corresponding 95\% confidence intervals (CIs), and associated p-values were estimated via unconditional logistic regression. The Chi-square $\left(\chi^{2}\right)$ was used to compare the gender distribution, test the association between the genotypes and alleles in relation to the controls, and test for deviation of the genotype distribution from Hardy - Weinberg equation (HWE).

\section{RESULTS}

MDM2 SNP309 polymorphism was identified using the restriction fragment length polymorphism-polymerase chain reaction (RFLPPCR) method. Table 1 shows the demographic characteristics of the study population. The distribution of sex, age, and ethnic origin of the study population was similar. MDM2 SNP309 gene polymorphism was identified in 301 healthy individuals. The mean age of the study population was found to be $49,80 \pm 16,4$ years $(51,97 \pm 15,98$ years in men and 47,58 $\pm 16,82$ years in women) (Table 1). Genotype distribution of the study population was consistent with the HardyWeinberg equilibrium (HWE) ( $\chi 2: 3.77, P: 0.455)$. The frequencies of TT, TG, and GG genotypes were $17.9 \%, 55.2 \%$ and $26.9 \%$, respectively. When the frequencies of $\mathrm{T}$ and $\mathrm{G}$ alleles were investigated, $\mathrm{T}$ allele was found to be 0.43 and $\mathrm{G}$ allele was $0.57(\chi 2: 17.82, P: 0.001)$ (Table 2). Figure 1 shows the results of the analysis of rs2279744 polymorphism of MDM2 gene localized in the region 12q13-14 of chromosome. 
Table 1. Characteristics of the study population

\begin{tabular}{cc}
\hline & Healthy individuals \\
\hline Sample size & 301 \\
Gender & $142(47,0)$ \\
Males & $159(53,0)$ \\
Females & \\
Age (year) & $15-90$ \\
Range & $49,80 \pm 16,4$ \\
Means \pm SD & $51,97 \pm 15,98$ \\
Males & $47,58 \pm 16,82$ \\
Females &
\end{tabular}

Table 2. Genotype frequencies for MDM22 rs2279744 polymorphism

\begin{tabular}{ccccc}
\hline $\begin{array}{c}\text { Genotype MDM2 } \\
\text { rs2279744(309 T>G) }\end{array}$ & $\begin{array}{c}\text { Sample size } \\
(\mathrm{n}=301)\end{array}$ & $\begin{array}{c}\text { Percentage } \\
(\%)\end{array}$ & $p$-values & $\chi^{2}$ \\
\hline $\begin{array}{c}\text { Allele Frequence } \\
\text { T allele }\end{array}$ & 274 & 45.5 & 0,001 & 17,82 \\
G allele & 328 & 54.5 & & \\
Genotype Frequence & 54 & 17,9 & & \\
TT & 166 & 55,2 & $0.0521^{\mathrm{a}}$ & 3,77 \\
TG & 81 & 26,9 & & \\
GG & 54 & 17,9 & & \\
Dominant & 247 & 82,1 & & \\
TT & & & & \\
TG + GG & 220 & 73,1 & & \\
Recessive & 81 & 26,9 & & \\
TT + TG & & & & \\
GG & 135 & 44.8 & & \\
Overdominant & 166 & 55.2 & \\
$T T+G G$ & & & \\
$T G$ & &
\end{tabular}

Hardy-Weinberg equilibrium;

Hardy Weinberg equilibrium (first degree of freedom $p>0.05$ if $x^{2}<3.84$ ) 


\section{DISCUSSION}

Single nucleotide polymorphisms represent the most common type of genetic variations found in human genome. There may be thousands of polymorphic genes in human genome, and the susceptibility of the individuals with these genetic variations to cancer may be affected ${ }^{12}$. In the present study, we aimed to determine the frequency of MDM2 gene rs2279744 polymorphism in a Turkish population consisting of healthy individuals. Genotype distributions and allele frequencies of this polymorphism in healthy individuals have been investigated. When rs2279744 (T309G) polymorphism was investigated in healthy individuals, 81 (26.9\%) were found to have GG, $166(55.1 \%)$ had TG, and $54(17.9 \%)$ had TT genotype. According to the MDM2 rs2279744 polymorphism, no statistically significant difference was found between the distribution of different genotypes ( $\chi 2: 3.77, p$ : $0.455)$. In a previous study performed in the Turkish population, Tuna et al. (2013) reported GG genotype in $23.9 \%$, TG in $56.3 \%$, and TT in $19.7 \%$ of healthy individuals ${ }^{13}$. Similarly, in the study of Petenkaya et al. (2006), the genotype distribution among a healthy study population was found as $26.0 \% \mathrm{GG}, 53.0 \% \mathrm{TG}$, and $21.0 \% \mathrm{TT}^{14}$ (Table 3). Comparison of the present study to these previous studies shows that the genotype distributions are highly similar. Based on these findings, it appears that there are a high number of individuals with TG genotype in the Turkish population. With a sample size of 301 individuals, the present study was larger from the previous studies in the Turkish population and this is a crucial aspect of epidemiological studies.

Table 3. Distribution of polymorphisms of $M D M 2$ rs2279744 genotype frequencies in different populations

\begin{tabular}{lcccccc}
\hline \multirow{2}{*}{ Country } & \multirow{2}{*}{ Year } & Sample & \multicolumn{3}{c}{ MDM2 (309 T>G) (\%) } & \multirow{2}{*}{ Ref } \\
\cline { 4 - 6 } & & size & TT & TG & GG & \\
\hline Japan & 2006 & 438 & 22,6 & 55,0 & 22,4 & $(21)$ \\
Korea & 2008 & 299 & 20,4 & 50,8 & 28,8 & $(31)$ \\
China & 2013 & 574 & 34,7 & 51,6 & 13,7 & $(23)$ \\
Finland & 2005 & 185 & 31,0 & 53,0 & 16,0 & $(24)$ \\
America & 2005 & 118 & 38,1 & 44,1 & 17,8 & $(32)$ \\
Italy & 2006 & 92 & 43,0 & 43,0 & 13,0 & $(20)$ \\
Spain & 2007 & 184 & 52,7 & 34,3 & 13,0 & $(26)$ \\
Austria and Poland & 2007 & 98 & 40,8 & 52,0 & 7,0 & $(27)$ \\
Tunisia & 2013 & 167 & 38,3 & 33,5 & 28,1 & $(30)$ \\
China & 2005 & 1420 & 29,4 & 50,1 & 20,5 & $(18)$ \\
America & 2010 & 454 & 38,5 & 43,8 & 17,6 & $(25)$ \\
China & 2011 & 132 & 35,6 & 53,8 & 10,6 & $(33)$ \\
China & 2012 & 226 & 22,1 & 52,2 & 25,7 & $(34)$ \\
Germany & 2010 & 499 & 37,1 & 46,9 & 16,0 & $(28)$ \\
Germany & 2012 & 350 & 40,3 & 47,1 & 12,6 & $(29)$ \\
Turkey & 2006 & 103 & 28,1 & 55,4 & 16,5 & $(19)$ \\
Turkey & 2010 & 110 & 42,7 & 43,6 & 13,6 & $(15)$ \\
Turkey & 2006 & 149 & 21,0 & 53,0 & 26,0 & $(14)$ \\
Turkey & 2013 & 75 & 20,0 & 49,3 & 30,7 & $(13)$ \\
Turkey & $\mathbf{2 0 1 7}$ & $\mathbf{3 0 1}$ & $\mathbf{1 7 , 9}$ & $\mathbf{5 5 , 2}$ & $\mathbf{2 6 , 9}$ & This study \\
\hline
\end{tabular}

Recently, Akkı, $\mathrm{H}$ et al. identified a SNP (rs2279744) at position 309 of the promoter region of MDM2 gene which results in $\mathrm{T} \rightarrow \mathrm{G}$ nucleotide replacement in patients with hepatocellular carcinoma. The researchers reported a significant relation between $\mathrm{G}$ allele of the SNP309 that occurs in promoter of $M D M 2$ gene and the development of hepatocellular carcinoma ${ }^{15}$. Various studies from other countries reported an association between the aforementioned SNP in position 309 of $M D M 2$ gene and gastric carcinoma ${ }^{7}$ non-small cell lung cancer ${ }^{16}$, endometrial cancer ${ }^{17}$, squamouscell carcinoma of the esophagus ${ }^{18}$ and bladder cancer $^{19}$. MDM2 rs2279744 polymorphism is a functional polymorphism that effects intracellular p53 protein levels. Replacement of $\mathrm{G}$ allele by $\mathrm{T}$ allele increases the binding affinity of $\mathrm{Sp} 1$ transcription activator. Therefore, expression of the $M D M 2$ gene increases. Over-expression of MDM2 prevents $p 53$ functions as well as aiding in the escape of damaged cells from cell cycle checkpoints and becoming carcinogenic ${ }^{8,9}$. The 
allele frequencies in the present study were found to be 0.57 for $\mathrm{G}$ and 0.43 for $\mathrm{T}$ allele. When the allele frequencies were statistically evaluated, the allele frequency of individuals with $\mathrm{G}$ allele was found to be significantly increased $(\chi 2: 17.82$, $P: 0.01$ ) (Table 2). Another study from Turkey previous reported these frequencies as 0.48 for $\mathrm{G}$ allele and 0.52 for $\mathrm{T}$ allele, which were highly comparable to our findings ${ }^{14}$. Several studies performed in other countries demonstrated an elevated risk of cancer among individuals with $\mathrm{G}$ allele ${ }^{20-22}$. Thus, considering available data, MDM2 rs2279744 polymorphism can increase the susceptibility to cancer in the Turkish population.

When the genotype distribution found in the present study was compared to the data for different ethnic origins as demonstrated in Table 3, GG genotype frequency appeared to be similar to Japanese population $^{21}$. GG genotype frequency in this study was higher than that reported in China ${ }^{23}$, Finland ${ }^{24}$, America ${ }^{24,25}$, Italy ${ }^{20}$, Spain ${ }^{26}$, Austria and Poland $^{27}$, Germany ${ }^{28}$, Germany and Romania ${ }^{29}$ and lower than in Tunisia ${ }^{30}$ and Korea. Moreover, the maximum and minimum GG genotype frequencies recorded in different countries were $30.7 \%$ and $7.0 \%$, respectively. GG genotype frequency, as found to be $26.9 \%$ in this study, was within this range.

In conclusion, the present study provided essential information on allele and genotype distribution of MDM2 SNP309 polymorphism in a Turkish population. In addition to the data on MDM2 gene polymorphism in a Turkish population, the findings of this study provide a framework for future studies that would investigate the role of MDM2 protein on susceptibility to various diseases, particularly cancer.

\section{REFERENCES}

1. Freedman DA, Levine AJ. Nuclear export is required for degradation of endogenous $\mathrm{p} 53$ by MDM2 and human papillomavirus E6. Mol Cell Biol 1998; 18: 7288-93.

2. Schlott T, Reimer S, Jahns A, Ohlenbusch A, Ruschenburg I, Nagel H, et al. Point mutations and nucleotide insertions in the MDM2 zinc finger structure of human tumours. J Pathol 1997; 182: 54-61.

3. Giaccia AJ, Kastan MB. The complexity of p53 modulation: emerging patterns from divergent signals. Gene Dev 1998; 12: 297383.
4. Rocco JW, Sidransky D. p16(MTS$1 / \mathrm{CDKN} 2 / \mathrm{INK} 4 \mathrm{a}$ ) in cancer progression. Exp Cell Res 2001; 264: 42-55.

5. Michael D, Oren M. The p53-Mdm2 module and the ubiquitin system. Semin Cancer Biol 2003; 13: 49-58.

6. Momand J, Wu HH, Dasgupta G. MDM2 master regulator of the p53 tumor suppressor protein. Gene 2000; 242: 15-29.

7. Bond GL, $\mathrm{Hu} \mathrm{WW}$, Levine A. A single nucleotide polymorphism in the MDM2 gene: From a molecular and cellular explanation to clinical effect. Cancer Res 2005; 65: 5481-4.

8. Momand J, Zambetti GP, Olson DC, George D, Levine AJ. The Mdm-2 Oncogene Product Forms a Complex with the P53 Protein and Inhibits P53-Mediated Transactivation. Cell 1992; 69: 1237-45.

9. Zhang XM, Miao XP, Guo YL, Tan W, Zhou YF, Sun T, et al. Genetic polymorphisms in cell cycle regulatory genes MDM2 and TP53 are associated with susceptibility to lung cancer. Hum Mutat 2006; 27: 110-7.

10. Miller SA, Dykes DD, Polesky HF. A Simple Salting out Procedure for Extracting DNA from Human Nucleated Cells. Nucleic Acids Res 1988; 16: 1215.

11. Yilmaz M, Tas A, Kacan T, Sari M, Silig Y. Is there a relation between Murine double minute 2 T309G polymorphism and lung cancer risk in the Turkish population? Turk $\mathbf{J}$ Biochem 2017; 42: 123-9.

12. Ekmekci A, Konac E, I OH. Gen polimorfizmi ve kansere yatknlık. Marmara Medical Journal 2008; 21: 282-95.

13. Tuna G, Kucukhuseyin O, Arikan S, Saglam EK, Guler E, Cacina C, et al. Do CDKN2 p16 $540 \mathrm{C}>\mathrm{G}, \mathrm{CDKN} 2 \mathrm{p} 16580 \mathrm{C}>\mathrm{T}$, and MDM2 SNP309 T > G Gene Variants Act on Colorectal Cancer Development or Progression? DNA Cell Biol 2013; 32: 4008.

14. Petenkaya A, Bozkurt B, Akilli-Ozturk O, Kaya HS, Gur-Dedeoglu B, Yulug IG. Lack of association between the MDM2-SNP309 polymorphism and breast cancer risk. Anticancer Res 2006; 26: 4975-7.

15. Akkiz H, Sumbul AT, Bayram S, Bekar A, Akgollu E. MDM2 promoter polymorphism is associated with increased susceptibility to hepatocellular carcinoma in Turkish 
population. Cancer Epidemiol 2010; 34: 44852.

16. Lind H, Zienolddiny S, Ekstrom PO, Skaug V, Haugen A. Association of a functional polymorphism in the promoter of the MDM2 gene with risk of nonsmall cell lung cancer. Int J Cancer 2006; 119: 718-21.

17. Walsh CS, Miller CW, Karlan BY, Koeffler HP. Association between a functional single nucleotide polyrnorphism in the MDM2 gene and sporadic endometrial cancer risk. Gynecol Oncol 2007; 104: 660-4.

18. Hong Y, Miao XP, Zhang XM, Ding F, Luo AP, Guo YL, et al. The role of P53 and MDM2 polymorphisms in the risk of esophageal squamous cell carcinoma. Cancer Res 2005; 65: 9582-7.

19. Onat OE, Tez M, Ozcelik T, Toruner GA. MDM2 T309G polymorphism is associated with bladder cancer. Anticancer Res 2006; 26: 3473-5.

20. Menin C, Scaini MC, De Salvo GL, Biscuola M, Quaggio A, Esposito G, et al. Association between MDM2-SNP309 and age at colorectal cancer diagnosis according to $\mathrm{p} 53$ mutation status. J Natl Cancer 2006; 98: 2858.

21. Ohmiya N, Taguchi A, Mabuchi N, Itoh A, Hirooka Y, Niwa Y, et al. MDM2 promoter polymorphism is associated with both an increased susceptibility to gastric carcinoma and poor prognosis. J Clin Oncol 2006; 24 : 4434-40.

22. Yoon YJ, Chang HY, Ahn SH, Kim JK, Park YK, Kang DR, et al. MDM2 and p53 polymorphisms are associated with the development of hepatocellular carcinoma in patients with chronic hepatitis B virus infection. Carcinogenesis 2008; 29: 1192-6.

23. Pan XL, Li YQ, Feng J, Wang XY, Hao B, Shi $\mathrm{RH}$, et al. A functional polymorphism T309G in MDM2 gene promoter, intensified by Helicobacter pylori lipopolysaccharide, is associated with both an increased susceptibility and poor prognosis of gastric carcinoma in Chinese patients. Bmc Cancer 2013; 13.

24. Alhopuro P, Ylisaukko-oja SK, Koskinen WJ, Bono P, Arola J, Jarvinen HJ, et al. The MDM2 promoter polymorphism SNP309T -> $\mathrm{G}$ and the risk of uterine leiomyosarcoma, colorectal cancer, and squamous cell carcinoma of the head and neck. J Med Genet 2005; 42: 694-8.

25. Liu G, Cescon DW, Zhai R, Zhou W, Kulke MH, Ma C, et al. p53 Arg72Pro, MDM2 T309G and CCND1 G870A polymorphisms are not associated with susceptibility to esophageal adenocarcinoma. Dis Esophagus 2010; 23: 36-9.

26. Alazzouzi H, Suriano G, Guerra A, Plaja A, Espin E, Armengol M, et al. Tumour selection advantage of non-dominant negative P53 mutations in homozygotic MDM2-SNP309 colorectal cancer cells. J Med Genet 2007; 44: 75-80.

27. Talseth BA, Meldrum C, Suchy J, Kurzawski G, Lubinski J, Scott RJ. MDM2 SNP309 T > $\mathrm{G}$ alone or in combination with the TP53 R72P polymorphism does not appear to influence disease expression and age of diagnosis of colorectal cancer in HNPCC patients. Int J Cancer 2007; 120: 563-5.

28. Grochola LF, Muller TH, Bond GL, Taubert H, Udelnow A, Wurl P. MDM2 SNP309 Associates with accelerated pancreatic adenocarcinoma formation. Pancreas 2010; 39: 76-80.

29. Zimmer V, Hoblinger A, Mihalache F, Assmann G, Acalovschi M, Lammert F. Potential genotype-specific single nucleotide polymorphism interaction of common variation in p53 and its negative regulator mdm2 in cholangiocarcinoma susceptibility. Oncol Lett 2012; 4: 101-6.

30. Chaar I, Amara S, Khiari M, Ounissi D, Dhraif M, Ben Hamida AM, et al. Relationship Between MDM2 and p53 Alterations in Colorectal Cancer and Their Involvement and Prognostic Value in the Tunisian Population. Appl Immunohisto M M. 2013; 21: 228-36.

31. Cho YG, Choi BJ, Song JH, Kim CJ, Cao Z, Nam SW, et al. No association of MDM2 T309G polymorphism with susceptibility to Korean gastric cancer patients. Neoplasma 2008; 55: 256-60.

32. Sotamaa K, Liyanarachchi S, Mecklin JP, Jarvinen $\mathrm{H}$, Aaltonen LA, Peltomaki P, et al. p53 codon 72 and MDM2 SNP309 polymorphisms and age of colorectal cancer onset in Lynch syndrome. Clin Cancer Res 2005; 11: 6840-4.

33. LI R, Zhang L, Liu Z, Hou C-p, Zhang Y-x, Wang Z-j, et al. Correlation of MDM2 gene 
polymorphisms and risk of esophageal squamous cell carcinoma in southwest shandong han nationality. Xinxiang Yi Xue Yuan Xue Bao 2011; 28: 437-42.

34. Ma J, Zhang JN, Ning T, Chen ZP, Xu CQ. Association of genetic polymorphisms in MDM2, PTEN and P53 with risk of esophageal squamous cell carcinoma. J Hum Genet 2012; 57: 261-4.

35. Tas A, Atabey M, Caglayan M, Bostanci EM, Bolukbasi SS, Topcu O, Silig Y. Investigation of the association between the MDM2 T309G polymorphism and gastric cancer. Biomedical Reports 2017 (doi.org/10.3892/br.2017.978). 